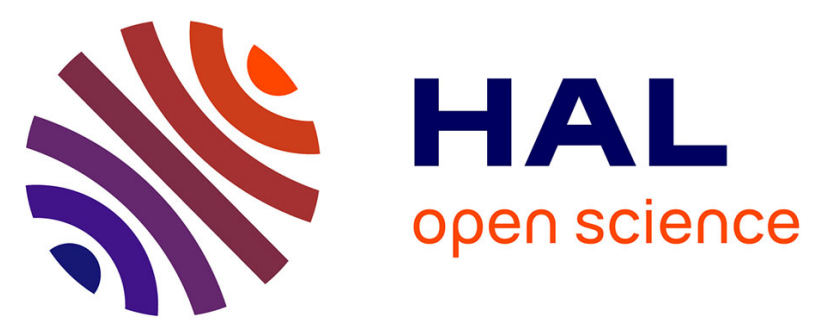

\title{
Urban Solid Waste: An Analysis of Energy Recovery Efficiency Three Different Treatment Systems in Brazil
}

Geslaine Frimaio, Adrielle Frimaio, Cezar Augusto Frimaio, Cecília Almeida

\section{To cite this version:}

Geslaine Frimaio, Adrielle Frimaio, Cezar Augusto Frimaio, Cecília Almeida. Urban Solid Waste: An Analysis of Energy Recovery Efficiency Three Different Treatment Systems in Brazil. IFIP International Conference on Advances in Production Management Systems (APMS), Sep 2016, Iguassu Falls, Brazil. pp.805-811, 10.1007/978-3-319-51133-7_94. hal-01615773

\section{HAL Id: hal-01615773 \\ https://hal.inria.fr/hal-01615773}

Submitted on 12 Oct 2017

HAL is a multi-disciplinary open access archive for the deposit and dissemination of scientific research documents, whether they are published or not. The documents may come from teaching and research institutions in France or abroad, or from public or private research centers.
L'archive ouverte pluridisciplinaire HAL, est destinée au dépôt et à la diffusion de documents scientifiques de niveau recherche, publiés ou non, émanant des établissements d'enseignement et de recherche français ou étrangers, des laboratoires publics ou privés.

\section{(c)(1)}

Distributed under a Creative Commons Attribution| 4.0 International License 


\title{
Urban Solid Waste: An Analysis of Energy Recovery Efficiency Three Different Treatment Systems in Brazil
}

\author{
Geslaine Frimaio $^{13}$, Adrielle Frimaio ${ }^{1}$, Cezar Augusto Frimaio ${ }^{2}$, and Cecília \\ M.V.B. Almeida ${ }^{1}$ \\ 1 UNIP, São Paulo, Brazil \\ gfrimaio@gmail.com \\ 2 UFABC, São Paulo, Brazil \\ 3 IFSULDEMINAS, Brazil
}

\begin{abstract}
The final disposal of urban solid waste has become a major concern in a world where urbanization is a trend. In this study three different systems were analyzed by accounting renewable, non-renewable and paid resources in a common basis, with the emergy accounting methodology, so it is possible to obtain ratios and indices that aid the comprehension, management and enable the comparison among the three system: landfill, pyrolysis and plasma arc. The systems are now operating, except for the arc plasma, which is under implementation in the municipality of Hortolândia-SP. The indices show that the landfill with electricity production is the system with better performance for 5 out of 6 indexes. For every gram of USW treated, the landfill can produce $1.78 \times 1016$ joules of electricity, which means that this system is 5 times more efficient than the pyrolisis and the plasma arc systems in this scope.
\end{abstract}

Keywords: Urban solid waste $\cdot$ Emergy $\cdot$ Landfill

\section{Introduction}

During the Agenda 21 meeting of the United Nations [1], the majority of the countries committed on adopting policies that would lower the environmental impacts caused by the Urban Solid Waste (USW), based on the principles of sustainable development.

In Brazil Law 12.305/10 was sanctioned, which says about the Solid Waste National Policy [2] and stablishes the recovery of materials and the decrease on waste generation. Concerning to the treatment, Law 12.305 enforces that waste must be either treated thermally or disposed in landfills. Considering that USW is a heterogeneous fuel, this energy could be recovered either as biogas on landfills or gas from synthesis on thermal treatments.

The generation of electricity in one of the landfills has been occurring since the 1070's [3]. The organic matter is decomposed by methanogenic bacteria, which release biogas that will be converted into electricity on combustion engines. 
Plasma torch as a technology for USW treatment started to be used in the 1980's on the United States, Europe and Japan [4]. The organic share of waste is converted into synthesis gas (syngas) in a reactor where the temperature may reach up to $10,000^{\circ} \mathrm{C}$. Afterwards, syngas goes through a cooling and cleaning process and is used for producing electricity on turbines [4].

On the pyrolysis process the waste is decomposed on the pyrolytic reactor, where the chemical decomposition occurs due to the heat of waste, without oxygen and in temperatures ranging from $400^{\circ} \mathrm{C} 1000^{\circ} \mathrm{C}$ [5]. The CUW (Carbonized Urban Waste) from this process goes through a process of briquetting and pressing that will feed the pyrolytic reactor [6].

Researches using Life Cycle Assessment (LCA) stress that pyrolysis, gasification and plasma torch are more efficient for energy recovery, if compared to the incineration process $[5,7]$, and the landfill should be the last option to be considered (PNRS, 2010).

Several studies employ the emergy synthesis to assess the possibilities, limitations, potentialities and the sustainability of USW treatment technologies, for example: $[8,9,10,11,12]$.

\section{Methodology}

\subsection{System Description}

Landfill São João occupies 80 hectares in the municipality of São Paulo and has received 29 million tons of USW during the 17 years it has worked. In 2008, one year after it was closed, São João Energia Ambiental was implemented and started producing electricity capable of fulfilling the demand of a city with 400,000 inhabitants.

Projeto Natureza Limpa is located in the municipality of Unaí-MG. It started operating in 2014 and uses pyrolisys technology to treat 17,500 ton/year of USW. It occupies $18,000 \mathrm{~m}^{2}$ and has daily treatment capacity of 70 tons of USW, operating 16 hours per day, 365 days per year. The coal obtained (CUW) is used as a feedback to the pyrolytic reactor and the exceeding production is sold on the market.

The plasma torch technology is under studies for implantation in a project designed for the municipality of Hortolândia-SP. The design aims to treat 94,900 ton/year in $30,000 \mathrm{~m}^{2}-200$ ton/day of USW and 60 ton/day of waste from industry, hospitals and sewage sludge, operating 22 hours per day and 256 days per year.

\subsection{Methodology}

Emergy synthesis is a methodology developed by H.T. Odum in the early 80 's. Emergy (spelled with M) is defined as the energy demanded, direct or indirectly, to obtain a good or service, and it s unit is the sej (joules of solar emergy). All the inputs for implementing and operating the system, carachterized as energy 
flows, are converted into a common basis, called joules of solar emergy (sej), for which calculation we use the transformity $(\operatorname{sej} / J)$ if the flows are expressed in joules or the UEV (Unit Emergy Value) if the flows are expressed in other measures (sej/unit). This conversion enables to include on the global accounting of the system all the work performed by the men, as well as that performed by nature to obtain each flow of the system.

The emergy accounting table enables to determine the transformity and/or UEV of the good or service under study. The UEV may be used as an indicator of efficiency: a high value would say that the system has made a great effort to obtain one unit of the good or service.

The emergy synthesis, according to [13], is performed in four stages: designing the diagram of energy flows, building the environmental accounting table, calculating the indicators (Table 1) and discussion of the results.

Table 1. Indicators used on the USW systems assessment

\begin{tabular}{|c|c|}
\hline Indicator & Observation \\
\hline Recovered Energy & $\begin{array}{l}\text { Energy of prod- Indicates the efficiency of the sys- } \\
\text { uct }(\mathrm{J}) / \text { mass } \\
\text { of tem, able to provide the amount of } \\
\text { recovered joules from one gram of } \\
\text { USW. }\end{array}$ \\
\hline Recovered Emergy & $\begin{array}{l}\text { Recovered } \begin{array}{l}\text { Energy Allows estimating the quantity of } \\
(\mathrm{J}) \mathrm{x}\end{array} \text { Transformity emergy that the system can recover } \\
(\mathrm{sej} / \mathrm{J})\end{array}$ \\
\hline Net Emergy & $\begin{array}{l}\text { Recovered Emergy Indicates how much emergy the sys- } \\
\text { (sej/g) - emergy per tem recovers. The higher the index, } \\
\text { gram of USW(sej/g) the better the system. }\end{array}$ \\
\hline Emergy Investment Recovery & $\begin{array}{l}\text { Recovered Emergy Indicates the cost-benefit, measures } \\
\text { (sej/year)/ Used the advantage, in emergy, that the } \\
\text { emergy (sej/year) } \\
\text { system may get compared to all the } \\
\text { emergy used for the treatment. The } \\
\text { higher the value, the greater will be } \\
\text { the benefit obtained by the system } \\
\text { - in emergy. }\end{array}$ \\
\hline Emergy balance & $\begin{array}{l}\text { Total emergy of Indicates how much emergy the sys- } \\
\text { system (sej/year) - tem spends. The lower the index, } \\
\text { Recovered emergy the better for the system. } \\
\text { (sej/year) }\end{array}$ \\
\hline
\end{tabular}

\section{Results and Discussion}

Every interaction within the treatment systems during the processes, as well as with the landscape may be observed on the diagrams. The energy diagram 
for the landfill is showed on Fig. 1, the plasma torch system on Fig. 2 and the pyrolysis on Fig. 3.

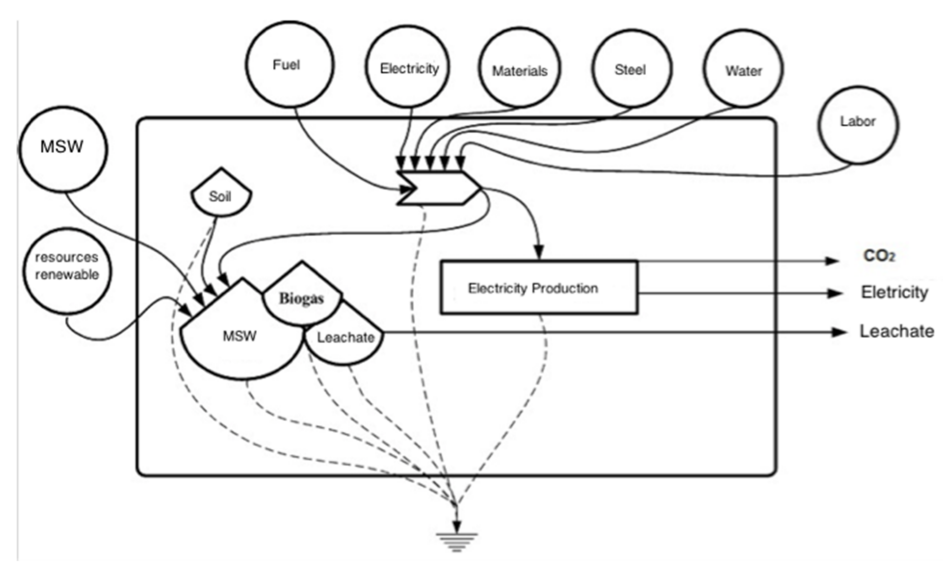

Fig. 1. Landfill energy diagram

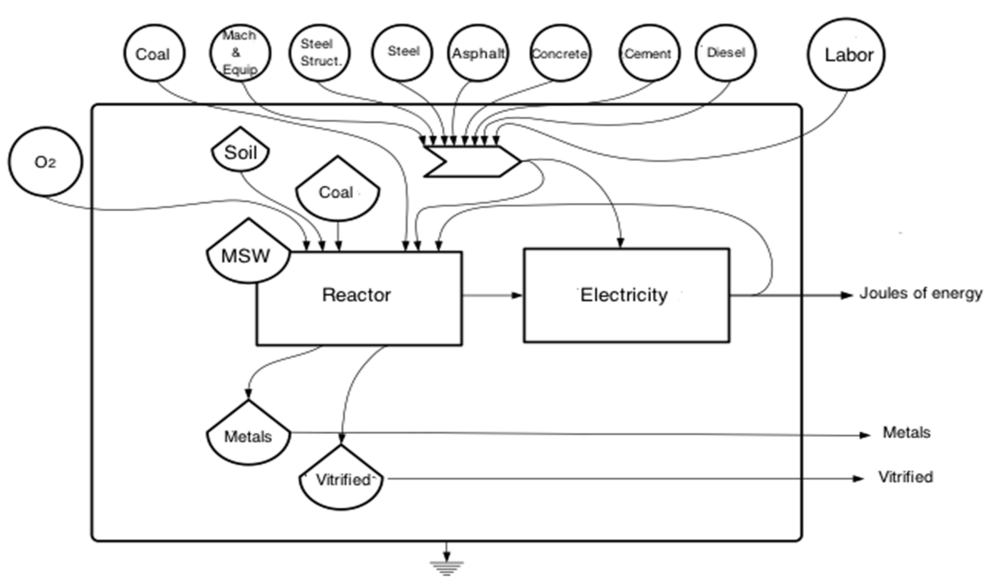

Fig. 2. Plasma torch energy diagram

On Table 2 the results of the emergy accounting for each system, as well as the yearly amount of USW treated in each system.

The electricity on the operation stage is the most significant flow for the systems of thermal treatment, representing $52 \%$ of the total for the pyrolysis 


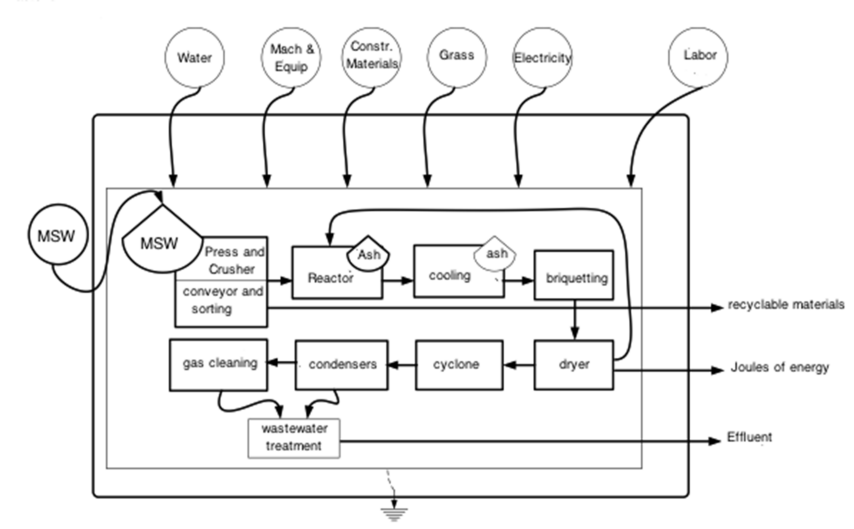

Fig. 3. Pyrolysis treatment system energy diagram

Table 2. Emergia total dos sistemas

\begin{tabular}{|c|c|c|c|}
\hline & Landfill & lasma Arc & Pyrolysis \\
\hline TOTAL EMERGY (sej) & $1,93 \times 1020$ & $4,35 \times 1018$ & $2,32 \times 1018$ \\
\hline Treated USW (g) & $5,72 \times 1011$ & $9,49 \times 1010$ & $1,75 \times 1016$ \\
\hline
\end{tabular}

and $34.5 \%$ for the plasma torch system, due to the reactors of both. On the landfill the most significant flow is the Oxygen (O2), responding for $63.1 \%$ of the flows and used to burn methane on the motogenerators.

Table 3. UEV(s) of systems

\begin{tabular}{lrrr}
\hline Indicators Landfill & Plasma Arc & Pyrolysis \\
\hline $\mathrm{UEV}(\mathrm{sej} / \mathrm{g})$ & $3.37 \times 108$ & $4.58 \times 107$ & $1.33 \times 108$ \\
\hline
\end{tabular}

UEV is an indicator that may be used to compare the efficiency of the waste treatment system. It comprehends the ratio between the emergy used by the system and the total emergy of the treated USW for this indicator the plasma arc is three times more efficient than the pyrolysis system to treat 1 gram of USW and about 2.5 times more efficient if compared to the landfill. Table 4 shows two indicators: Net Emergy and Recovered Emergy. The latter highlights that the landfill recovers $4.59 \times 109$ sej per gram of treated USW. The landfill is about 30 times more efficient on emergy recovery when it is compared to the pyrolysis system and about 26 times more efficient compared to the plasma arc. For the Net Emergy indicator the landfill has also shown the best performance: 
it is 30 times more efficient than the plasma arc system and 198 times more efficient than the pyrolysis.

Table 4. Results for net emergy and recovered emergy

\begin{tabular}{|c|c|c|c|}
\hline Indicators & Landfill & Plasma Arc & Pyrolysis \\
\hline NET EMERGY (sej/g) & $4.61 \times 109$ & $1.45 \times 108$ & $2.32 \times 107$ \\
\hline RECOVERED EMERGY (sej/g) & $4.95 \times 109$ & $1.91 \times 108$ & $1.56 \times 108$ \\
\hline
\end{tabular}

The results for Recovered Energy, Emergy Investment Recovery (EIR) and Emergy Balance are shown. The landfill is the system which recovers the greatest amount in joules of energy per gram of USW - about 8.5 times more than the other systems. Recovered emergy is the ratio between the recovered emergy and that one used to treat one gram of USW. This indicator stresses that the plasma arc system is 3.5 times more profitable in terms of emergy than the pyrolysis system, as it is able to recover more of the invested emergy due to the greater production of energy per gram of treated USW. For the indicator Emergy Recovery Index, the landfill showed to be 12.5 times more efficient that the pyrolysis system and this relations is 3.5 times greater compared to the plasma arc system.

Table 5. Results of indicators for recovered energy, emergy investment recovery and emergy balance

\begin{tabular}{crrr}
\hline & Landfill & Plasma & Arc Pyrolysis \\
\hline RECOVERED ENERGY & $3.11 \times 104$ & $3.64 \times 103$ & $3.11 \times 105$ \\
EIR (sej/sej) & 14.66 & 4.16 & 1.19 \\
EMERGY BALANCE & $1.93 \times 1020$ & $4.35 \times 1018$ & $2.32 \times 1019$ \\
\hline
\end{tabular}

For the Emergy Balance, the system that obtained the best index was the pyrolysis, 2 times more efficient than the plasma arc system and 8 times more efficient when compared to the landfill with electricity generation. Regarding that the landfill is the waste treatment system that obtains the greatest amount of energy joules per gram of treated waste, it means, that recovers more energy on its product and which recovered energy is considered a component for calculating most of the indicators, it is possible to say that the landfill with electricity production is the most effective option to recover or generate energy from USW. It is also the treatment system that has the greatest share of renewable resources (about $60 \%$ of $\mathrm{O} 2$ ). 


\section{Acnowledgement:}

CAPES, UNIP and IFSULDEMINAS, RGT International, Projeto Natureza Limpa as well as Alexandre Citvaras (Fox Ambiental).

\section{References}

1. CNUMAD: http://www.mma.gov.br/estruturas/agenda21/_arquivos/cap01. pdf

2. Brazil: Política Nacional de Resíduos Sólidos: Lei 12.305 de 02 de agosto de 2010, http://www.planalto.gov.br/ccivil_03/_Ato9.2007-2010/2010/Lei/ L12305.htm

3. Tammemagi, H.Y.: The Waste Crisis: Landfills, Incinerators, and the Search for a Sustainable Future. Oxford University Press, New York (1999)

4. Ducharme, C.: Technical and Economic Analysis of Plasma-assisted Waste-toEnergy Processes. Ph.D. thesis, Columbia University, Columbia (210)

5. Zaman, A.U.: Life Cycle Assessment of Pyrolysis-gasification as an Emerging Municipal Solid Waste Treatment Technology. International Journal of Environmental Science and Technology 10(5), 1029-1038 (2013)

6. Tôrres Filho, A.: Aplicação do Processo de Pirólise para Valoração, Cogeração de Energia e Tratamento de Resíduos. Ph.D. thesis, Federal de Minas Gerais, Belo Horizonte (2014)

7. Chakraborty, M., Sharma, C., Pandey, J., Gupta, P.K.: Assessment of Energy Generation Potentials of MSW in Delhi under Different Technological Options. Energy Conversion and Management 75, 249-255 (2013)

8. Tiezzi, E.: Analisi di Sostenibilitá Ambientale del Trattamento dei Rifiuti nel Comune di Modena (1998)

9. Luchi, F., Ulgiati, S.: Energy and Emergy Assessment of Municipal Waste Collection: A Case Study. In: Proceedings of the 1st Biennial Emergy Analysis Research Conference. pp. 303-316. University of Florida, Gainesville (2000)

10. Bastianonil, S., Porcelli, M., Pulsellil, M., F.: Emergy Evaluation of Comporting Municipal Solid Waste. WIT Transactions on Ecology and the Environment (56), 243-252 (2002)

11. Rugani, B., Pulselli, R.M., Niccolucci, V., Bastianoni, S.: Environmental Performance of a XIV Century Water Management System: An Emergy Evaluation of Cultural Heritage. Resources, Conservation and Recycling 56(1), 117-125 (2011)

12. Zhang, X.H., Deng, S., Jiang, W., Zhang, Y., Peng, H., Li, L., Yang, G., Li, Y.: Emergy evaluation of the sustainability of two industrial systems based on wastes exchanges. Resources, Conservation and Recycling 55(2), 182-195 (2010)

13. Odum, H.T.: Environmental Accounting: Emergy and Environmental Decision Making. Wiley and Sons (2005), http://www.wiley.com/WileyCDA/WileyTitle/ productCd-0471114421.html 